\title{
Injuries in Portuguese Amateur Youth Football Players: A Six Month Prospective Descriptive Study
}

\section{Lesões em Jovens Jogadores Portugueses de Futebol Amador: Estudo Prospetivo Descritivo Durante Seis Meses}

\author{
Miguel NOGUEIRA ${ }^{1}$, Rita LAIGINHAS ${ }^{2}$, José RAMOS ${ }^{3}$, Ovídio COSTA ${ }^{3}$
}

Acta Med Port 2017 Dec;30(12):840-847 - https://doi.org/10.20344/amp.8835

\begin{abstract}
Introduction: This study analyzed the incidence and characteristics of injuries sustained by amateur youth football players in Portugal during season 2015 - 2016.

Material and Methods: This is an observational descriptive study. We analyzed Portuguese youth football players' injuries over six months of a season. A total of 529 players were divided according to their age in two groups (Under-17 and Under-19). Data on injuries were collected.
\end{abstract}

Results: Throughout all 62062.0 hours of exposure recorded, 248 injuries were reported in 173 different players. The average incidence of injury was $3.87(95 \% \mathrm{Cl}=2.81 ; 4.94)$ per 1000 hours of football exposure. There was a significantly higher average incidence of injury during matches $-14.22(95 \% \mathrm{Cl}=10.35 ; 18.09)$ per 1000 hours of exposure - when compared to the average incidence of injury during training $-2.06(95 \% \mathrm{Cl}=1.22 ; 2.90)$ per 1000 hours of exposure. This significance was also observed when the comparison was made within each age group. A traumatic mechanism was involved in $76.6 \%$ of all the injuries, while overuse was reported in $12.9 \%$. The most common type was the injury that affected muscles and tendons $(52.8 \%)$. The body location most commonly affected by injuries was the thigh $(24.6 \%)$.

Discussion: Even though is essential a better characterization of Portuguese athletes of younger age groups such as those discussed in this study, the results of the studied population are in agreement with the existing literature. However, this study provides more information that may be important to better target the Portuguese athletes' training for injury prevention.

Conclusion: This study provides descriptive data on injuries developed in a subpopulation of Portuguese amateur youth football players that could represent a focus for future prevention.

Keywords: Athletic Injuries; Incidence; Portugal; Soccer/injuries

\section{RESUMO}

Introdução: Este estudo foi projetado com o intuito de analisar a incidência e as características das lesões desenvolvidas pelos jovens jogadores portugueses de futebol amador durante a época de 2015 - 2016.

Material e Métodos: Trata-se de um estudo observacional descritivo. Foram analisadas as lesões de jovens atletas durante seis meses de uma época. Um total de 529 jogadores foi dividido em dois grupos, atendendo à sua idade (Sub-17 e Sub-19). Os dados foram colectados semanalmente pelo responsável por cada equipa.

Resultados: Ao longo de 62 062,0 horas de exposição registadas, foram reportadas 248 lesões em 173 jogadores. A incidência de lesão média foi de $3,87(95 \% \mathrm{Cl}=2,81 ; 4,94)$ por 1000 horas de exposição a futebol. A incidência de lesão média durante os jogos $14,22(95 \% \mathrm{Cl}=10,35 ; 18,09)$ por 1000 horas de exposição - foi significativamente superior à incidência de lesão média durante os treinos $-2,06(95 \% \mathrm{Cl}=1,22 ; 2,90)$ por 1000 horas de exposição. Esta significância foi também observada quando feita a comparação dentro de cada grupo etário (Sub-17 e Sub-19). O mecanismo traumático esteve envolvido em $76,6 \%$ das lesões, enquanto que o mecanismo de sobre-utilização foi causa de $12,9 \%$ das lesões. As lesões mais frequentemente observadas foram as que envolveram músculos e tendões (52,8\%). A coxa foi a localização mais comum das lesões $(24,6 \%)$.

Discussão: Apesar de ser essencial uma melhor caracterização dos atletas Portugueses de grupos etários mais novos como os abordados neste estudo, os resultados da população estudada vão de encontro ao que existe na literatura mundial. No entanto, este estudo é mais uma fonte de informação que poderá ser importante para melhor direcionar o treino dos atletas portugueses para a prevenção de lesões.

Conclusão: Este estudo fornece informação descritiva das lesões ocorridas numa sub-população de jovens jogadores portugueses de futebol amador, podendo representar um foco para futura prevenção.

Palavras-chave: Futebol/lesões; Incidência; Lesões em Atletas; Portugal

\section{INTRODUCTION}

Physical exercise is seen as an essential part of a healthy lifestyle by providing individuals with benefits ranging across emotional, mental, social and physical spheres. ${ }^{1}$ As such, there is an increased understanding of the importance of sports activities, beginning in childhood. ${ }^{2}$

Football has the largest fan base internationally and is gaining momentum as the fastest growing sport worldwide with approximately 265 million registered football players, most of them under the age of $18 .^{3-5}$ Portugal follows this trend: football holds the highest number of registered

1. Faculdade de Medicina. Universidade do Porto. Porto. Portugal.

2. Serviço de Oftalmologia. Centro Hospitalar de Entre o Douro e Vouga. Santa Maria da Feira. Portugal.

3. Serviço de Medicina Desportiva. Departamento de Medicina. Faculdade de Medicina. Universidade do Porto. Porto. Portugal.

$\triangle$ Autor correspondente: Miguel Nogueira. mimed11037@med.up.pt

Recebido: 11 de fevereiro de 2017 - Aceite: 01 de novembro de 2017 | Copyright @ Ordem dos Médicos 2017 
players and most of them are young boys competing in amateur leagues. ${ }^{6}$ As a consequence of this elevated number of players, research to date also recognizes football as one of the leading causes of sports injuries..$^{7,8}$ The serious consequences that may result from injuries among the youth population (including, but not limited to, early bone disease, high medical costs, and a decrease in physical activity) are responsible for the heightened awareness to this topic. ${ }^{6,9}$ Research has demonstrated regional differences in the incidence of injury in European football $^{10}$ thus highlighting the relevance of introducing country-specific preventive strategies in the early stages of the players' careers. To achieve this goal, epidemiological data on injury characteristics and population-specific risk factors must be collected. ${ }^{11}$ In Portugal there is a lack of information on this topic. This study aims to investigate the incidence and characteristics of football-related injuries among young amateur football players in Portugal. These findings may inform future prevention programs in order to reduce injuries among players and cut down on associated medical costs.

\section{MATERIAL AND METHODS}

\section{Study design/setting}

This is a descriptive epidemiological study. A total of 51 football teams belonging to a northern district of Portugal - Aveiro - were invited to take part in the study. From these, 21 accepted the invitation. A follow-up of six months (26 weeks) of one season was planned. This study was approved by the Ethics Committee of the Faculty of Medicine of Porto University and is reported in line with the Strenghtening the Reporting of Observational Studies in Epidemiology (STROBE) statement. ${ }^{12}$

\section{Participants and study period}

Participants consisted of an all-male sample of youth amateur football players, ranging between 15 and 19 years of age. Age groups were divided according to Portugal's competition division: Under 17 years $(\mathrm{U}-17)$ and Under 19 years (U-19). Written informed consent according to the World Medical Association Declaration of Helsinki was requested to the athletes or the parents of minors to sign and were collected by the responsible of each team.

\section{Definition of injury/concepts}

Data acquisition was carried out according to the international consensus statement on injury definitions and procedures. $^{13}$

An injury was defined as any physical complaint sustained by a player resulting from a football match or football training. ${ }^{13}$ In accordance to the consensus, ${ }^{13}$ only time loss injuries (injuries that results in a player being unable to take a full part in future football training or a match) were reported.

Injury severity was defined according to the number of days that have elapsed from the date of injury to the date of the player's return to full participation in team training and availability for match selection (divided into four groups: minimal ( $1-3$ days), mild (4 - 7 days), moderate (8 - 28 days) and severe ( $\geq 29$ days). ${ }^{13}$

The location, type, mechanism and date of injury were collected. The resulting absence from sport, exposure in training and matches were documented. Injury mechanisms were classified into three groups: (1) traumatic (an injury resulting from a specific, identifiable event - divided in contact/noncontact), (2) overuse (an injury caused by repeated micro-trauma without a single, identifiable event

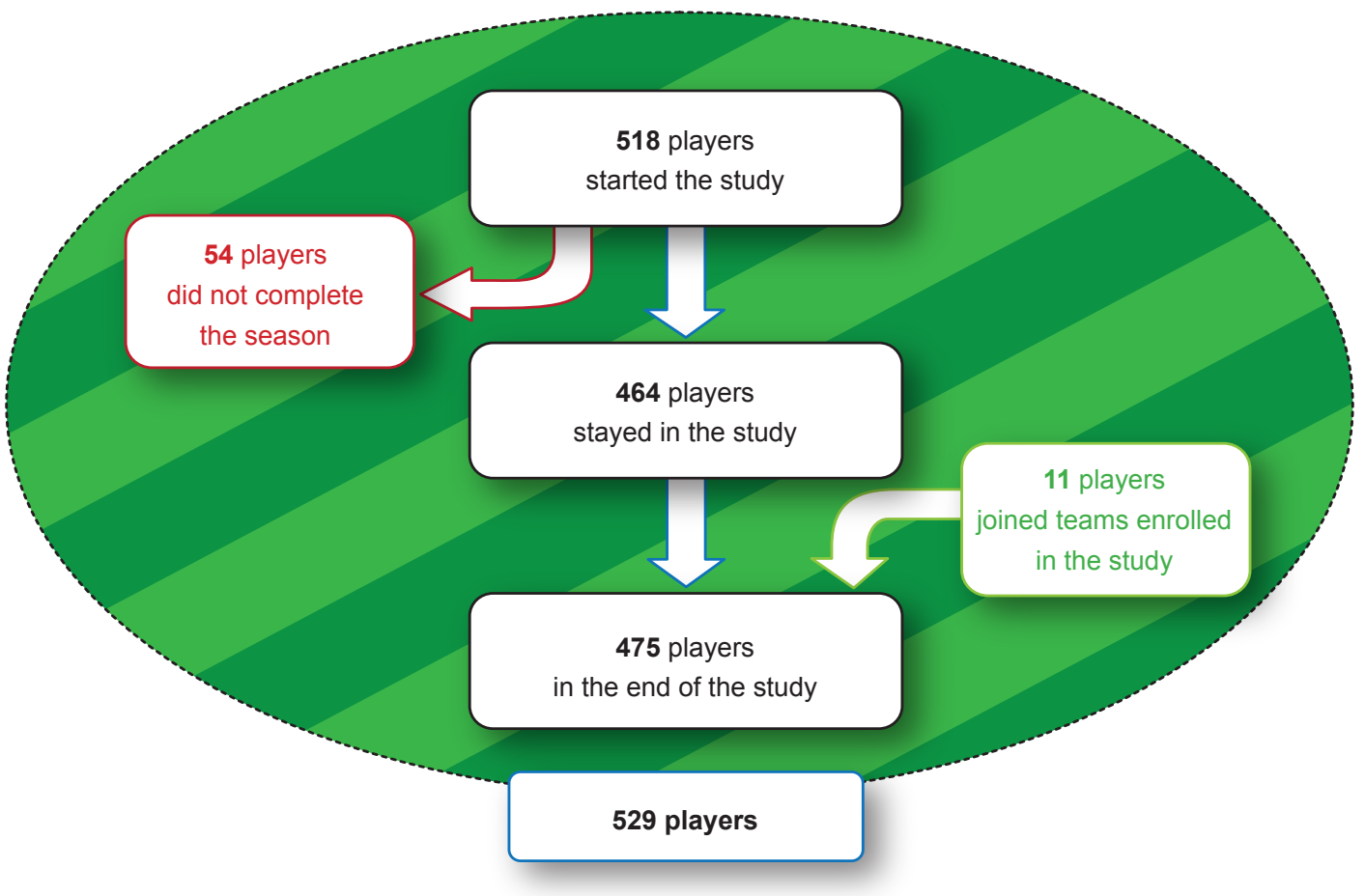

Figure 1 - Evolution of number of players throughout the season 
responsible for the injury) $)^{13}$ and (3) unknown, when there was no certainty about the associated mechanism.

A recurrent injury was defined as an injury of the same type and at the same site as an index injury and which occurs after a player's return to full participation from the index injury. ${ }^{13}$ However, we only considered a recurrence when the previous injury had occurred during the evaluated season.

Possible related factors were also gathered (position and dominant side - preferred leg for kicking - of the injured player, need for more comprehensive medical evaluation).

\section{Data collection}

Before the study started, all the teams elected a responsible person (the team coach/physical therapist) for transmitting the medical information to the investigator. A form was planned to gather information and thus standardize the collecting procedure. In a first meeting, the investigators made a brief presentation about the purpose of the study, the reporting system, the form and relevant definitions. Any doubt or additional information was clarified by phone call or via scheduled meeting. During the 26 weeks, the teams were regularly (weekly) contacted via email correspondence or phone call or visited in a scheduled meeting.

Data on exposure was collected on a team basis. ${ }^{13}$ Exposure time for training/match was reported by the responsible person of each team, as well as absence time of players due to an injury. The average length of a $\mathrm{U}-17$ match is 80 minutes and $90 \mathrm{~min}$ for $\mathrm{U}-19$. The average length of the training session was 90 minutes for both groups.

\section{Bias}

The field positions of players, despite being collected at the beginning of the study, were not consistent throughout the season. It is common for youth players and in amateur leagues to frequently change their field positions depending on the needs of the team. Data on exposure to different charges/intensity patterns was not also collected.
All reporting systems are subject to information bias, and ours is not an exception. However, this last one was improved by selection of one fixed responsible person per football team to report the injuries.

\section{Statistical methods}

Incidence of injury per 1000 hours of football participation (I) was calculated on a team basis as $I=(n / e) \times 1000$, where $\mathrm{n}$ is the number of injuries sustained and e the exposure time expressed as total hours of football participation. Rate ratio (RR) was used to compare the incidences. ${ }^{14}$ Normal distribution was checked using Shapiro-Wilk test or skewness and kurtosis. Gaussian-distributed variables were compared using $t$-tests. For non-normally distributed variables, Mann-Whitney test was performed. Variances were checked with Levene test. Significance was set at 0.05. All analyses were performed using $\mathrm{IBM}^{\circledR} \mathrm{SPSS}^{\circledR}$ Statistics (version 22.0; SPSS Inc.; Chicago) for Windows ${ }^{\circledR}$.

\section{RESULTS}

Follow-up occurred in season 2015/2016 (a period from $1^{\text {st }}$ of November 2015 until 30 $30^{\text {th }}$ of April 2016 - total of 26 weeks, excluding holiday breaks). The 21 teams that were enrolled in the study provided an initial sample of 518 players (286 U-17 and $232 \mathrm{U}-19$ ) that started on day one. During the six-month period there was a loss to follow-up of 54 players (representing $10.2 \%$ from the total number of participants - 529 players). This resulted mainly from the end of the career of the player or because of a move to other teams not covered by the study. Additionally, during the follow-up period, two players moved to a team included in the study and 11 new players joined teams participating in the study. However, based on the intention-to-treat standard and although our study is not a randomized one, ${ }^{15}$ all available data for the total number of participants (529) were included in the final analysis.

Detailed information about the number of injuries, time of exposure and incidence by each team enrolled in the study is available in Appendix 1

Table 1 - Number of players, time of exposure, number of injuries and their incidence per 1000 hours of exposure by age group. Incidence values were first calculated for each team and the presented values correspond to an extracted average incidence and not to direct calculation.

\begin{tabular}{|c|c|c|c|c|}
\hline & Number of players & Time of exposure, $\mathrm{h}$ & Injuries, n (\%) & Incidence / 1000h $(95 \% \mathrm{Cl})$ \\
\hline Under 17 & & 33673.0 & $138(55.6)$ & $3.74(1.96-5.51)+$ \\
\hline Training & 290 & 28598.5 & $73(29.4)$ & $2.14(0.64-3.64)^{*}$ \\
\hline Matches & & 5074.5 & $65(26.2)$ & $12.60(7.40-17.80)^{*}$ \\
\hline Under 19 & & 28389.0 & $110(44.4)$ & $4.02(2.53-5.52)+$ \\
\hline Training & 239 & 24561.0 & $46(18.5)$ & $1.97(0.94-3.01)^{*}$ \\
\hline Matches & & 3828.0 & $64(25.8)$ & $16.01(9.32-22.69)^{*}$ \\
\hline Total & & 62062.0 & $248(100)$ & $3.87(2.81-4.94)$ \\
\hline Training & 529 & 53159.5 & $119(48.0)$ & $2.06(1.22-2.90)^{\star}$ \\
\hline Matches & & 8902.5 & $129(52.0)$ & $14.22(10.35-18.09)^{*}$ \\
\hline
\end{tabular}

Values in parentheses represent \% of total (248) injuries.

$\mathrm{H}$ : hours; $\mathrm{n}$ : number of injuries; + Levene test: $p=0.680, T$-test: $p=0.787$ (statistically non significant when comparing average incidence of injury of Under $17 /$ Under 19 groups); ${ }^{*}$ Mann-Whitney test: $p<0.01$ (statistically significant when comparing average incidence of injury during training/matches in each group: Under 17 , Under 19 and Total) 
Table 2 - Number (percentage of total) of injuries among Portuguese amateur youth football players by location, type and severity

\begin{tabular}{|c|c|c|c|c|c|c|c|c|c|c|}
\hline Injury location & \multicolumn{2}{|c|}{$\begin{array}{c}\text { Minimal } \\
(1-3 \text { days }) \\
n(\%)\end{array}$} & \multicolumn{2}{|c|}{$\begin{array}{c}\text { Mild } \\
(4-7 \text { days }) \\
n(\%)\end{array}$} & \multicolumn{2}{|c|}{$\begin{array}{c}\text { Moderate } \\
(8-28 \text { days }) \\
n(\%)\end{array}$} & \multicolumn{2}{|c|}{$\begin{array}{c}\text { Severe } \\
(\geq 29 \text { days }) \\
n(\%)\end{array}$} & \multicolumn{2}{|c|}{$\begin{array}{l}\text { Total } \\
\text { n (\%) }\end{array}$} \\
\hline Thigh & 8 & $(3.2)$ & 22 & $(8.8)$ & 27 & $(10.8)$ & 4 & $(1.6)$ & 61 & $(24.6)$ \\
\hline *Posterior & 4 & $(1.6)$ & 10 & $(4.0)$ & 15 & $(6.0)$ & 2 & $(0.8)$ & 31 & (12.5) \\
\hline${ }^{*}$ Anterior & 4 & $(1.6)$ & 12 & $(4.8)$ & 12 & $(4.8)$ & 2 & $(0.8)$ & 30 & (12.1) \\
\hline Ankle & 2 & $(0.8)$ & 10 & $(4.0)$ & 32 & (12.9) & 9 & (3.6) & 53 & $(21.4)$ \\
\hline Knee & 2 & $(0.8)$ & 9 & $(3.6)$ & 12 & $(4.8)$ & 11 & $(4.4)$ & 34 & $(13.7)$ \\
\hline Groin & 2 & $(0.8)$ & 3 & $(1.2)$ & 12 & $(4.8)$ & 9 & (3.6) & 26 & $(10.5)$ \\
\hline Shank/Achilles tendon & 5 & $(2.0)$ & 4 & $(1.6)$ & 4 & $(1.6)$ & 5 & (2.0) & 18 & $(7.3)$ \\
\hline Lower back & 4 & $(1.6)$ & 2 & $(0.8)$ & 6 & $(2.4)$ & 5 & $(2.0)$ & 17 & $(6.9)$ \\
\hline Foot/Toe & 5 & $(2.0)$ & - & $(0.0)$ & 4 & $(1.6)$ & 2 & $(0.8)$ & 11 & $(4.4)$ \\
\hline Pelvis/Hip & 3 & $(1.2)$ & 2 & $(0.8)$ & - & $(0.0)$ & 4 & $(1.6)$ & 9 & (3.6) \\
\hline Shoulder/Clavicles & - & $(0.0)$ & 1 & $(0.4)$ & 4 & $(1.6)$ & - & $(0.0)$ & 5 & $(2.0)$ \\
\hline Hand/Finger/Thumb & - & $(0.0)$ & 1 & $(0.4)$ & 3 & $(1.2)$ & 1 & $(0.4)$ & 5 & $(2.0)$ \\
\hline Thorax/Upper back & 1 & $(0.4)$ & 2 & $(0.8)$ & 1 & $(0.4)$ & - & $(0.0)$ & 4 & $(1.6)$ \\
\hline Wrist & - & $(0.0)$ & - & $(0.0)$ & 2 & $(0.8)$ & - & $(0.0)$ & 2 & $(0.8)$ \\
\hline Head/Face & 1 & $(0.4)$ & - & $(0.0)$ & - & $(0.0)$ & - & $(0.0)$ & 1 & $(0.4)$ \\
\hline Abdomen & - & $(0.0)$ & - & $(0.0)$ & - & $(0.0)$ & 1 & $(0.4)$ & 1 & $(0.4)$ \\
\hline Forearm & - & $(0.0)$ & 1 & $(0.4)$ & - & $(0.0)$ & - & $(0.0)$ & 1 & $(0.4)$ \\
\hline Total & $\underline{33}$ & $(13.3)$ & $\underline{57}$ & (22.9) & $\underline{107}$ & (43.1) & $\underline{51}$ & $\underline{(20.6)}$ & $\underline{248}$ & $(100.0)$ \\
\hline \multicolumn{11}{|l|}{ Type of injury } \\
\hline Fractures and bone stress & 1 & $(0.4)$ & 0 & $(0.0)$ & 0 & $(0,0)$ & 4 & $(1.6)$ & 5 & $(2.0)$ \\
\hline Muscle and tendon & 20 & $(8.1)$ & 34 & $(13.7)$ & 52 & $(21.0)$ & 25 & $(10.1)$ & 131 & $(52.8)$ \\
\hline Joint (non-bone) and ligament & 1 & $(0.4)$ & 12 & $(4.8)$ & 47 & $(19.0)$ & 20 & $(8.1)$ & 80 & $(32.3)$ \\
\hline Contusions & 11 & $(4.4)$ & 11 & $(4.4)$ & 8 & $(3.2)$ & 2 & $(0.8)$ & 32 & $(12.9)$ \\
\hline Total & $\underline{33}$ & $(13.3)$ & $\underline{57}$ & (23.0) & $\underline{107}$ & (43.1) & $\underline{51}$ & $(20.6)$ & $\underline{248}$ & $(100.0)$ \\
\hline
\end{tabular}

Values in parentheses represent $\%$ of total (248) injuries.

$\mathrm{N}$ : number of injuries

(https://www.actamedicaportuguesa.com/revista/index. php/amp/article/view/8835/5272), which can be consulted to better understand the extracted average incidence values that will be referred throughout the article.

The average exposure time was 2955.3 hours [95\% confidence interval $(\mathrm{Cl})=2452.6,3458.1]$. A total of 248 injuries were recorded in 173 players $(32.7 \%$ of total participants). The average incidence of injury was 3.87 per 1000 hours $(95 \% \mathrm{Cl}=2.81 ; 4.94)$. There were no significant differences when comparing $\mathrm{U}-17$ and $\mathrm{U}-19$ average incidence of injury $(\mathrm{RR}=1.07 ; p=0.787)$. The average incidence of injury during matches was higher when compared to the average incidence of injury during training sessions $(\mathrm{RR}=6.90 ; p<0.01)$. For detailed information see Table 1.

Only $11.2 \%$ of all injuries were confirmed by complementary physical examination: $6.0 \%$ by radiography, $4.0 \%$ by ultrasound and $1.2 \%$ by magnetic resonance imaging (MRI). All other diagnoses were the responsibility of the medical department of each club.

\section{Injury location}

A higher prevalence of injuries in the lower limbs was observed ( $n=212 ; 85.5 \%$ ). The majority of injuries were located on the thigh ( $n=61 ; 24.6 \%$ ), followed by the ankle $(n=53 ; 21.4 \%)$. For detailed information see Table 2.

\section{Type}

Most common type was the injury that affected the muscle and tendon ( $n=131 ; 52.8 \%)$ followed by the joints and ligaments $(n=80 ; 32.3 \%)$ (Table 2$)$.

\section{Severity}

A total of 4639 days were lost and each injury accounted for an average of $18.6(95 \% \mathrm{Cl}=16.07 ; 21.10)$ days lost.

The majority of injuries had a recovery period between 8 to 28 days (moderate severity) ( $n=107 ; 43.1 \%)$. The most severe injuries occurred in the knee $(n=11 ; 4.4 \%)$ followed by the groin and the ankle (both with $n=9 ; 3.6 \%$ ). Minimal injuries were registered mostly on the thigh $(n=8 ; 3.2 \%)$. Severe injuries occurred predominantly in the muscle and tendon ( $n=25 ; 10.1 \%$ ). For detailed information see Table 2 . 
Table 3 - Incidence of injury by mechanism and their recurrence (by training session and match). Incidence values were first calculated for each team and the presented values correspond to an extracted average incidence and not to direct calculation.

\begin{tabular}{|c|c|c|c|c|}
\hline & \multicolumn{4}{|c|}{ U-17 } \\
\hline & \multicolumn{2}{|c|}{ Training } & \multicolumn{2}{|c|}{ Match } \\
\hline & $\begin{array}{l}\text { Injury } \\
\mathrm{n}(\%)\end{array}$ & $\begin{array}{c}\text { Incidence/ } 1000 \mathrm{~h} \\
(95 \% \mathrm{Cl})\end{array}$ & $\begin{array}{l}\text { Injury } \\
\mathrm{n}(\%)\end{array}$ & $\begin{array}{c}\text { Incidence/ } 1000 \mathrm{~h} \\
(95 \% \mathrm{Cl})\end{array}$ \\
\hline \multicolumn{5}{|l|}{ Mechanism } \\
\hline $\begin{array}{l}\text { Traumatic } \\
\text { Contact } \\
\text { Non-contact }\end{array}$ & $\begin{array}{c}51(21.6) \\
16(6.5) \\
35(14.1)\end{array}$ & $\begin{array}{l}1.39(0.13-2.66)^{\alpha} \\
0.46(0.04-0.88) \\
0.93(0.01-1.85)\end{array}$ & $\begin{array}{c}53(21.4) \\
31(12.5) \\
22(8.9)\end{array}$ & $\begin{array}{c}10.62(6.12-15.13)^{*} \\
5.89(3.20-8.58) \\
4.73(1.15-8.32)\end{array}$ \\
\hline Overuse & $14(5.6)$ & $0.51(0.11-0.91)^{\alpha}$ & $7(2.8)$ & $1.26(-0.16-2.69)^{*}$ \\
\hline Unknown & $8(3.2)$ & - & $5(2.0)$ & - \\
\hline Total & $73(29.4)$ & $2.14(0.64-3.64)$ & $65(26.2)$ & $12.60(7.40-17.80)$ \\
\hline \multicolumn{5}{|l|}{ Recurrence } \\
\hline Reccurent injury & $17(6.9)$ & $0.52(0.11-0.94)+$ & $2(0.8)$ & $0.29(-0.14-0.72)+$ \\
\hline Injury for the first time & $56(22.6)$ & $1.62(0.46-2.78)+$ & $63(25.4)$ & $12.31(7.20-17.42)+$ \\
\hline Total & $73(29.4)$ & $2.14(0.64-3.64)$ & $65(26.2)$ & $12.60(7.40-17.80)$ \\
\hline
\end{tabular}

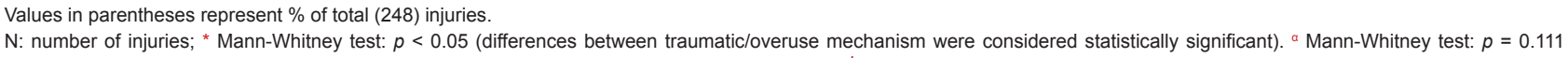
(differences between traumatic/overuse mechanism were not considered statistically significant); + Mann-Whitney test: $p<0.05$ (differences between recurrent/first-time injury were considered statistically significant)

\section{Mechanism of injury}

As we can see in Table 3, most of the injuries were caused by traumatic mechanism (RR $=5.35 ; p<0.05)$. In U-17, traumatic injuries were significantly than overuse injuries only in matches $(\mathrm{RR}=8.43 ; p<0.05)$ while in $\mathrm{U}-19$ the traumatic mechanism was responsible for most injuries in both matches $(\mathrm{RR}=7.61 ; p<0.05)$ and training $(\mathrm{RR}=$ 5.79; $p<0.05)$.

\section{Injuries recurrence}

The incidence of first-time injuries exceeded recurrence $(R R=6.11 ; p<0.05)$, as we can see in Table 3.

\section{Dominant side}

When comparing lower limb non-contact injuries by dominance we found that most of the injuries occurred in the dominant leg (Table 4).

\section{DISCUSSION}

Our study analyzed the incidence of injuries and their characteristics in Portuguese amateur football players. We evaluated 248 injuries and thus calculated an average incidence of injury of 3.87 per 1000 hours of exposure $(95 \% \mathrm{Cl}=2.81 ; 4.94)$. We found no significant differences when comparing the average incidence of injury between $\mathrm{U}-17$ and U-19 groups. A significantly higher incidence of injury occurred during matches when compared with training sessions, and traumatic injuries also registered a higher incidence when compared with overuse mechanism. Although we observed a significantly higher incidence of first-time injures comparing with recurrent injuries in our study, the comparison with other studies cannot be made because of our previously mentioned different definition of recurrence.
Currently, there is a gap in the literature about the incidence of injuries and characteristics in young amateur football players. Therefore, the following study represents an important contribution by providing descriptive data from the Portuguese context.

\section{Outcomes contextualization Incidence of injury}

We found an average incidence of injury of 3.87 per 1000 hours of exposure $(95 \% \mathrm{Cl}=2.81 ; 4.94)$. Faude et a ${ }^{16}$ provided an extensive review of the existing literature on time loss injuries in young football players until 2013, finding values of incidence between 2 and 7 per 1000 hours of exposure, which is in agreement with our results.

It is important to note that the incidence figures found in groups of youth amateur football players, ${ }^{6,17}$ such as the one of the sample that we examined, is lower when comparing with the values of studies involving elite players. ${ }^{18,19}$

\section{Injuries in matches versus training sessions}

Our data demonstrates a significantly higher incidence of injury in matches than in training sessions (14.22 per 1000 hours of match exposure $(95 \% \mathrm{Cl}=10.35 ; 18.09)$ versus 2.06 per 1000 hours of training exposure $(95 \% \mathrm{Cl}=1.22$; 2.90), $R R=6.90, p<0.001$. This pattern is also observed in each age group. These results corroborate existing literature,$^{20-23}$ whereby the overall incidence of injury during training varies from 1 - 5 injuries per 1000 hours and with 15 - 20 injuries per 1000 hours of match time (RR match to training sessions varies between 1.2 and 11.5$).{ }^{16}$

\section{Injuries and aging}

Some studies report an increase in the incidence of injury with age progression, linking it to enhanced competitiveness 
$\mathrm{U}-19$

Training

Match

Injury

Incidence/ $1000 \mathrm{~h}$

$(95 \% \mathrm{Cl})$

Injury

Incidence/ $1000 \mathrm{~h}$

$(95 \% \mathrm{Cl})$

$\underline{\text { Total }}$

$\mathrm{n}(\%)$

Total

Incidence/ $1000 \mathrm{~h}$ $(95 \% \mathrm{Cl})$

\begin{tabular}{cccccc}
$33(13.3)$ & $1.39(0.70-2.07)^{*}$ & $53(21.4)$ & $13.02(6.60-19.44)^{*}$ & $190(76.6)$ & $2.94(2.08-3.79)^{*}$ \\
$12(4.8)$ & $0.48(0.09-0.86)$ & $22(8.9)$ & $5.01(2.17-7.85)$ & $81(32.6)$ & $1.22(0.85-1.59)$ \\
$21(8.5)$ & $0.91(0.27-1.55)$ & $31(12.5)$ & $8.00(3.28-12.73)$ & $109(44.0)$ & $1.72(1.10-2.34)$ \\
$5(2.0)$ & $0.25(-0.07-0.57)^{*}$ & $6(2.4)$ & $1.71(0.06-3.36)^{*}$ & $32(12.9)$ & $0.55(0.28-0.82)^{*}$ \\
$8(3.2)$ & - & $5(2.0)$ & - & $26(10.5)$ & - \\
$46(18.5)$ & $1.97(0.94-3.01)$ & $64(25.8)$ & $16.01(9.32-22.69)$ & $248(100.0)$ & $3.87(2.81-4.94)$ \\
$8(3.2)$ & $0.35(-0.06-0.75)+$ & $9(3.6)$ & $2.15(0.58-3.71)+$ & $36(14.5)$ & $0.54(0.27-0.81)+$ \\
$38(15.3)$ & $1.63(0.84-2.41)+$ & $55(22.2)$ & $13.86(8.40-19.32)+$ & $212(85.5)$ & $3.33(2.47-4.20)+$ \\
$46(18.5)$ & $1.97(0.94-3.01)$ & $64(25.8)$ & $16.01(9.32-22.69)$ & $248(100.0)$ & $3.87(2.81-4.94)$ \\
\hline
\end{tabular}

among players ${ }^{16,21}$ and increased player-to-player contact. ${ }^{24}$ Although no significant differences were observed among the analyzed groups, the lack of observable difference may result from the close proximity of the age of the players enrolled in the study (15 to 19 years).

\section{Most common location of injury}

The authors found that players sustained more injuries in the lower limbs $(n=212 ; 85.5 \%)$ than in the upper limbs. Ergün et $a^{21}$ and Owoeye et $a^{23}$ report similar results; the literature that we consulted ${ }^{10,16}$ estimates that lower limb injuries account for approximately $60 \%$ - $90 \%$ of all football injuries.

When examining specific location of the body, most injuries occurred in the thigh ( $n=61 ; 24.6 \%$ ), a finding that is also in accordance to existing research. ${ }^{10,20,25,26}$ Recent studies dealing with professional football players demonstrate that thigh muscles injuries represent more than $30 \%$ of all injuries and cause higher number of days away from competition. ${ }^{27}$ Corazza et $a^{27}$ explained these numbers: thigh muscles achieve a high level of exposure by crossing two joints (hamstrings, gracilis and rectus femoris), all of which are essential to various football movements such as sprinting, jumping and kicking.

\section{Most common mechanism of injury}

We found more injuries caused by a traumatic mechanism when compared to overuse, either in match and training sessions $(\mathrm{RR}=5.35 ; p<0.05)$. This observation strengthens existing data. ${ }^{10,21,23}$ Football is a highly competitive sport and at younger ages the traumatic injuries are more common than the injuries caused by chronic accumulation of stress.

Table 4 - Non-contact lower limb injuries by dominance and location

\begin{tabular}{|c|c|c|c|c|c|c|}
\hline \multirow{2}{*}{$\begin{array}{l}\text { Injury Location } \\
\text { Thigh }\end{array}$} & \multicolumn{2}{|c|}{$\begin{array}{c}\text { Dominant leg } \\
\mathrm{n}(\%)\end{array}$} & \multicolumn{2}{|c|}{$\begin{array}{c}\text { Non-dominant leg } \\
\mathrm{n}(\%)\end{array}$} & \multicolumn{2}{|c|}{$\begin{array}{l}\text { Total } \\
\mathrm{n}(\%)\end{array}$} \\
\hline & 28 & (22.9) & 13 & (10.7) & 41 & $(33.6)$ \\
\hline Posterior & 17 & (13.9) & 13 & (10.7) & 30 & $(24.6)$ \\
\hline Anterior & 11 & $(9.0)$ & 0 & $(0.0)$ & 11 & $(9.0)$ \\
\hline Ankle & 18 & $(14.8)$ & 6 & $(4.9)$ & 24 & $(19.7)$ \\
\hline Groin & 15 & $(12.3)$ & 8 & $(6.6)$ & 23 & $(18.9)$ \\
\hline Knee & 11 & $(9.0)$ & 5 & $(4.1)$ & 16 & $(13.1)$ \\
\hline Shank/Achilles tendon & 5 & $(5.0)$ & 7 & $(5.7)$ & 12 & $(9.8)$ \\
\hline Pelvis/Hip & 3 & (2.5) & 3 & (2.5) & 6 & $(4.9)$ \\
\hline Total & 80 & $(65.6)$ & 42 & $(34.4)$ & 122 & $(100.0)$ \\
\hline
\end{tabular}

Values in parentheses represent \% of total (122) non-contact lower limb injuries

$\mathrm{N}$ : number of injuries 
Injury severity and return to play

Analyzing the level of severity, the authors found that the majority of the injuries $(43.1 \%)$ were responsible for an absence of 8 to 28 days and the minority $(13.3 \%)$ led to an absence of 1 to 3 days. These results are again consistent with previous findings in the literature, although the number of severe injuries was slightly higher in our study comparing to the existing data. ${ }^{16,23}$

\section{Dominant side injuries}

For the purpose of this study, the dominant leg was defined as the leg that the football player primarily prefers to use when kicking the ball. The data collected shows that injuries occurred at a higher percentage in the dominant leg when compared to the non-dominant leg $(65.6 \%$ vs $34.4 \%$ ) when considering only non-contact injuries. This is in accordance with existing research. ${ }^{28-31}$ Daneshjoo et $a^{28}$ suggests that this difference supports the hypothesis that physical performance and the movement patterns involved in football may negatively alter the balance of strength in both legs, known as bilateral strength balance. Negative changes to bilateral strength can be reduced through the use of simple and inexpensive strength balance compensation training ${ }^{32}$ devised by coaches and physical therapists.

\section{Comparison with existent Portuguese data}

As mentioned previously, there is a void in current Portuguese sports injury research. Only two similar studies were identified in the literature and with smaller sample sizes in the age groups compared in our study. The first study found an injury incidence of 1.2 per 1000 hours of exposure, a slightly lower value than the present study. ${ }^{6}$ However, this last one enrolled athletes between age 12 and 19 and, as previously mentioned, the incidence of injury tends to be lower in younger ages. For that reason, the total incidence value that they found may be underestimated when comparing to our older population and the direct comparison between studies cannot be made. Brito et $a^{/ 6}$ found similar patterns of location and mechanism predominance. Sousa $\mathrm{P}$ et $a^{\beta 3}$ similarly examined amateur Portuguese football players however focusing on adult ones (18 - 38 years of age).

\section{Limitations}

Our study has some limitations that we must underline. The classification of injuries and the period of occurrence were solely ascertained by the medical staff of each team. Additionally, injuries were only classified as recurrent if they had occurred during the evaluative season which may have led to an underestimation in the recurrence rate. It was not possible to eliminate this last limitation due to a lack of access to the past medical histories of players.

The 2006 consensus $^{13}$ introduced some level of uniformity in injury criteria thereby contributing to less biased comparisons. However not all existing studies adopt consensus in the classification and nomenclature of football injuries and this limited the comparison between our results and those from other studies.

The exposure time was recorded and based on a plan proposed by the technical team department of each club in the beginning of the study and the changes (in the plan or in the athletes involved) were communicated throughout the follow-up period. However, there may be some cases where the exposure time was over or underestimated because of unreported changes. We did not have access to information about training plans or charge and intensity of players' exposure, and this data may have improved our analysis. The dropouts also constitute a limitation that we could not control.

\section{CONCLUSION}

Our incidence rates agree with the existing literature. We found no significant differences when comparing the average incidence of injury between both age groups (U17 vs U-19). We found a significantly higher incidence of injury during matches when comparing to training sessions; traumatic injuries also registered a higher incidence when comparing with overuse ones, as well as recurrent injuries comparing with first-time injuries. Overall, the most frequently affected location was the thigh and the most common recovery period of injuries was between 8 to 28 days. Considering injuries that were not caused by contact with the opponent, we verified a higher occurrence in the dominant side of the athletes.

This study emphasizes the importance of having more prospective data for better characterization of the Portuguese athletes and their injury patterns so that more consistent conclusions can be drawn.

\section{ACKNOWLEDGEMENTS}

We would like to thank all the players, coaches, directors, and medical staff from the teams of Aveiro divisions for their extremely valuable participation. We would also like to thank all those who have contributed in some way to the accomplishment of the project and article.

\section{PROTECTION OF HUMANS AND ANIMALS}

The authors declare that the procedures were followed according to the regulations established by the Clinical Research and Ethics Committee and to the Helsinki Declaration of the World Medical Association.

\section{DATA CONFIDENTIALITY}

The authors declare having followed the protocols in use at their working center regarding patients' data publication. Informed consent was duly obtained from the patient.

\section{CONFLICTS OF INTEREST}

All authors report no conflict of interest.

\section{FUNDING SOURCES}

This research received no specific grant from any funding agency in the public, commercial, or not-for-profit sectors. 


\section{REFERENCES}

1. Krustrup P, Nielsen J, Krustrup B, Christensen J, Pedersen H, Randers $\mathrm{M}$, et al. Recreational soccer is an effective health-promoting activity for untrained men. Br J Sports Med. 2009;43:825-31.

2. Benjamin E, Blaha M, Chiuve S, Cushman M, Das S, Deo R, et al. Heart disease and stroke statistics-2017 update: a report from the American Heart Association Circulation. 2017;135:e146-e603.

3. Maher $M$, Hutchison $M$, Cusimano $M$, Comper $P$, Schweizer $T$. Concussions and heading in soccer: a review of the evidence of incidence, mechanisms, biomarkers and neurocognitive outcomes. Brain Inj. 2014;28:271-85.

4. Silvers H. Injury prevention in the soccer athlete. SportEX Med. 2011;47:14-21.

5. FIFA Communications Division. FIFA Big Count 2006: 270 Million People Active in Football. Zurich: FIFA; 2007.

6. Brito J, Malina R, Seabra A, Massada J, Soares J, Krustrup P, et al. Injuries in Portuguese soccer players during training and match play. J Athl Train. 2012;47:191-7.

7. Dvorak J, Graf-Baummann T, Peterson L, Junge A. Football, or soccer, as it is called in North America, is the most popular sport wordwile. Am J Sports Med. 2000;28:S1-2.

8. Timpka T, Schyllander J, Stark D, Ekman R, Dahlström Ö, Hägglund $M$, et al. Community-level football injury epidemiology: traumatic injuries treated at Swedish emergency medical facilities. Eur J Public Health. 2017 (in press).

9. Emery C, Meeuwisse W, Hartmann S. Evaluation of risk factors for injury in adolescent soccer: implementation and validation of an injury surveillance system. Am J Sports Med. 2005;33:1882-91.

10. Waldén M, Hägglund M, Orchard J, Kristenson K, Ekstrand J. Regional differences in injury incidence in European professional football. Scand J Med Sci Sports. 2013;23:424-30.

11. van Mechelen W, Hobil $H$, Kemper $H$. Incidence, severity, etiology and prevention of sports injuries: a review of concepts. Sports Med. 1992;14:82-99.

12. Vandenbroucke J, von Elm E, Altman D, Gøtzsche P, Mulrow C, Pocock S, et al. Strengthening the Reporting of Observational Studies in Epidemiology (STROBE): explanation and elaboration. PLoS Med. 2007; 4:e297.

13. Fuller C, Ekstrand J, Junge A, Andersen T, Bahr R, Dvorak J, et al. Consensus statement on injury definitions and data collection procedures in studies of football (soccer) injuries. Br J Sports Med. 2006;40:193-201.

14. Fuller C, Dick R, Corlette J, Schmalz R. Comparison of the incidence, nature and cause of injuries sustained on grass and new generation artificial turf by male and female football players. Part 1: match injuries. Br J Sports Med. 2007;41:i20-6.

15. Yelland L, Sullivan T, Voysey M, Lee K, Cook J, Forbes A. Applying the intention-to-treat principle in practice: Guidance on handling randomization errors. Clin Trials. 2015;12:418-23.

16. Faude $O$, Rößler R, Junge $A$. Football injuries in children and adolescent players: are there clues for prevention? Sports Med. 2013;43:819-37.
17. Junge A, Cheung K, Edwards T, Dvorak J. Injuries in youth amateur soccer and rugby players - comparision of incidence and characteristics. Br J Sports Med. 204;38:168-72.

18. Le Gall F, Carling C, Reilly T, Vandewalle H, Church J, Rochcongar P. Incidence of injuries in elite French youth soccer players: a 10-season study. Am J Sports Med. 2006;34:928-38.

19. Nilsson $\mathrm{T}$, Östenberg $\mathrm{AH}$, Alricsson M. Injury profile among elite male youth soccer players in a Swedish first league. J Exerc Rehabil. 2016;12:83-9.

20. Bianco A, Spedicato M, Petrucci M, Messina G, Thomas E, Sahin F, et al. A prospective analysis of the injury incidence of young male professional football players on artificial turf. Asian J Sports Med. 2016;7:e28425.

21. Ergün M, Denerel H, Binnet M, Ertat K. Injuries in elite youth football players: a prospective three-year study. Acta Orthop Traumatol Turc. 2013;47:339-46.

22. Meeuwisse W, Tyreman H, Hagel B, Emery C. A dynamic model of etiology in sport injury: the recursive nature of risk and causation. Clin $\mathrm{J}$ Sport Med. 2007;17:215-9.

23. Owoeye O, Akinbo S, Tella B, Olawale O. Efficacy of the FIFA 11+ WarmUp Programme in male youth football: a cluster randomised controlled trial. J Sports Sci Med. 2014;13:321-8.

24. Gianotti M, Al-Sahab B, McFaull S, Tamim H. Epidemiology of acute soccer injuries in Canadian children and youth. Pediatr Emerg Care. 2011;27:81-5.

25. Grooms D, Palmer T, Onate J, Myer G, Grindstaff T. Soccer-specific warm-up and lower extremity injury rates in collegiate male soccer players. J Athl Train. 2013;48:782-9.

26. Tourny C, Sangnier S, Cotte T, Langlois R, Coquart J. Epidemiologic study of young soccer player's injuries in U12 to U20. J Sports Med Phys Fitness. 2014;54:526-35.

27. Corazza A, Orlandi D, Baldari A, Gatto P, Stellatelli M, Mazzola C, et al. Thigh muscles injuries in professional soccer players: a one year longitudinal study. Muscles Ligaments Tendons J. 2013;3:331-6.

28. Daneshjoo A, Rahnama N, Mokhtar A, Yusof A. Bilateral and unilateral asymmetries of isokinetic strength and flexibility in male young professional soccer players. J Hum Kinet. 2013;36:45-53.

29. Ekstrand J, Hägglund M, Waldén M. Epidemiology of muscle injuries in professional football (soccer). Am J Sports Med. 2011;39:1226-32.

30. Olumide A, Ajide K. Incidence and factors associated with injuries among adolescent players in an amateur soccer tournament in Nigeria. J Sports Med Phys Fitness. 2016;56:1026-33.

31. Svensson K, Eckerman M, Alricsson M, Magounakis T, Werner S Muscle injuries of the dominant or non-dominant leg in male football players at elite level. Knee Surg Sports Traumatol Arthrosc. 2016 (in press).

32. Soligard T, Myklebust G, Steffen K, Holme I, Silver H, Bizzini M, et al. Comprehensive warm-up programme to prevent injuries in young female footballers: cluster randomised controlled trial. BMJ. 2008;337:a2469.

33. Sousa P, Rebelo A, Brito J. Injuries in amateur soccer players on artificial turf: a one-season prospective study. Phys Ther Sport. 2013;14:146-51. 